\title{
Questionnaire Investigation on Tourists' Behavior and its Sensibility Analysis Utilizing Bayesian Network
}

\author{
Akane Okubo $^{1}$, Tsuyosi Aburai $^{2} \&$ Kazuhiro Takeyasu ${ }^{3}$ \\ ${ }^{1}$ NIHON University Junior College, Japan \\ ${ }^{2}$ Tokushima University, Japan \\ ${ }^{3}$ College of Business Administration, Tokoha University, Japan \\ Correspondence: Akane Okubo, NIHON University Junior College, Japan
}

Received: December 13, 2017

Accepted: December 28, 2017

Online Published: January 16, 2018

doi:10.5430/bmr.v7n1p11

URL: https://doi.org/10.5430/bmr.v7n1p11

\begin{abstract}
Tourists from abroad are increasing rapidly in Japan. Kawazu town in Izu Peninsula is famous for its cherry trees. In the cherry blossom season, many tourists visit this town. In order to get much more visitors, tourists' behavior should be investigated much further. The Kawazu Cherry Blossom Festival was carried out in February 2015. Our research investigation was performed during that period. In this paper, a questionnaire investigation is executed in order to clarify tourists' behavior, and to seek the possibility of developing regional collaboration among local government, tourism related industry and visitors. In this research, we construct the model utilizing Bayesian Network and causal relationship is sequentially chained by the characteristics of travelers, an objective to visit Izu Peninsula in Japan and the main occasion to visit them. We analyzed them by sensitivity analysis and some useful results were obtained. Sensitivity analysis is performed by back propagation method. We have presented the paper concerning this. But the volume becomes too large, therefore we have split them and this paper shows the latter half of the investigation result by setting evidence to Bayesian Network items. These are utilized for constructing a much more effective and useful tourism service. We have obtained fruitful results. To confirm the findings by utilizing the new consecutive visiting records would be the future works to be investigated.
\end{abstract}

Keywords: Tourism, Izu Peninsula, Kawazu Cherry Tree, Bayesian Network, Back Propagation

\section{Introduction}

In recent years in Japan, the national and local governments have been trying to attract foreign tourists by using strategic approaches and developing tourist facilities, with the aim of promoting regional exchange and generating economic benefits. Particular aims of local government are to overcome the common problems of an aging population and declining birthrate through tourism-generated income and to stimulate the local society through regional exchange and migration.

However, in order to take measures that will increase tourism, it is necessary to understand the attraction of particular regions in Japan, as well as the resources they offer to tourists. Moreover, it is necessary to have a picture of the tourists that might want to visit such regions.

Although it is useful to have an understanding of an issue at a given time and under specific social conditions, it is difficult to analyze chronological changes or cross-regional trends statistically. It is standard practice to design a survey such that it permits examination of the statistics for a given region over time, but in order to investigate solutions to problems shared across regions it is necessary to carefully examine the critical basic data as well as appropriate methods of data collection.

To try to obtain such data, preceding studies on tourist destinations that have statistically analyzed trends in tourist behavior will now be reviewed.

Yoshida et al. designed and conducted a visitor survey on the spot, which used a questionnaire to investigate the activities of visitors to the Ueno district in Taito ward, Tokyo. Doi et al. analyzed the image of the Izu Peninsula as a tourist destination in their 2003 study "Questionnaire Survey on the Izu Peninsula." Kano conducted tourist behavior studies in Atami city in 2008, 2009, 2014 and in other years.

In this paper, a questionnaire investigation was executed in Kawazu town in February 2015, which was conducted to 
coincide with events on the Izu Peninsula featuring flowers; the Kawazu Sakura Festival (Feb-Mar), and ways that regions can collaborate to carry out surveys of tourist behavior was also performed.

This survey of tourist behavior was carried out in February 2015, during the Kawazu Cherry Blossom Festival. Given the geographical peculiarities of Kawazu town and its relative lack of accommodation facilities, some of the survey personnel were located also at Izukyu-Inatori Station and Izukyu-Shimoda Station. On the first day of the survey, the weather was good, while on the second it was raining.

The 25th Kawazu Cherry Blossom Festival was held from February 10 to March 10, 2015. It was attended by 801,330 people, which was an increase of $9 \%$ over the previous year.

On the first day of the survey, 30-50\% of the flowers were in bloom, and the nighttime illuminations lit up on the evening of the 21st. According to the figures of the Kawazu town Tourist Association, there were 30,590 visitors on the 21 st and 20,913 visitors on the 22nd.

During the Kawazu Cherry Blossom Festival, around 150 stores were offering food \& drink or souvenirs on the road with the row of cherry trees linked to Kawazu Station. A number of events were held during the festival, including the "Semi Gourmet" and "Izu no Odoriko Photography Event."

In order to get much more visitors, tourists' behavior should be investigated much further.

In this paper, a questionnaire investigation is executed in order to clarify tourists' behavior, and to seek the possibility of developing regional collaboration among local government, tourism related industry and visitors. These are analyzed by using Bayesian Network.

The analysis utilizing Bayesian Network enabled us to visualize the causal relationship among items. Furthermore, sensitivity analysis brought us estimating and predicting the prospective visitors. Sensitivity analysis was conducted by back propagation method.

Some interesting and instructive results are obtained. We have presented the paper concerning this. But the volume becomes too large, therefore we have split them and this paper shows the latter half of the investigation result by setting evidence to Bayesian Network parameters. These are utilized for constructing a much more effective and useful tourism service.

The rest of the paper is organized as follows. Outline of questionnaire investigation is stated in section 2. In section 3, Bayesian Network analysis is executed which is followed by the sensitivity analysis in section 4 . Remarks is stated in section 5.

\section{Outline and the Basic Statistical Results of the Questionnaire Research}

\subsection{Outline of the Questionnaire Research}

We make a questionnaire investigation on tourists' behavior who has visited Izu Peninsula and is studied mainly at Kawazu town in Shizuoka Prefecture. Kawazu town is famous for its cherry trees. The outline of questionnaire research is as follows. Questionnaire sheet is attached in Appendix 1.

(1) Scope of investigation : Tourists who have visited Kawazu town in Shizuoka Prefecture, Japan

(2) Period

: February 21,22/ 2015

(3) Method

: Local site, Dispatch sheet, Self writing

(4) Collection

: Number of distribution 500

Number of collection 478(collection rate $95.6 \%$ )

Valid answer 478

\subsection{Basic Statistical Results}

The main summary results by single variable are as follows.

2.2.1 Characteristics of Answers (Q4)

(1) Sex (Q2)

Male $37.24 \%$, Female $59.83 \%$, (Not filled in 2.93\%)

(2) Age (Q3)

$10^{\text {th }} 2.51 \%, 20^{\text {th }} 14.23 \%, 30^{\text {th }} 12.76 \%, 40^{\text {th }} 13.18 \%, 50^{\text {th }} 18.41 \%, 60^{\text {th }} 17.78 \%$, More than $708.37 \%$, (Not filled in $12.76 \%)$ 
(3) Occupation (Q4)

Independents 3.77\%, Office worker $48.74 \%$, Student $4.81 \%$, Housewife $16.53 \%$, No job $12.13 \%$ Miscellaneous $1.26 \%$, (Not filled in 12.76\%)

(4) Residence (Q1)

Tokyo $28.16 \%$, Kanagawa 22.15\%, Shizuoka $10.35 \%$, Saitama 10.14\%, Chiba 6.63\%, Aichi $2.48 \%$, Tochigi $2.48 \%$, Ibaraki 1.86\%, Gunma 1.24\%, Yamanashi 1.24\%, Osaka 0.83\%, Nagano 0.83\%, Gifu 0.62\%, Fukushima 0.62\%, Miyagi0.62\%, Else

(5) Fellow travelers (Q5)

Solo trip 3.35\%, Couple 34.31\%, Family 28.45\%, Male's small group 3.77\%, Female's small group 12.76\%, Male and female's small group 7.95\%, Group(More than 7) 7.53\%, Miscellaneous $0.42 \%$, (Not filled in 1.46\%)

These are exhibited in Figure 1.

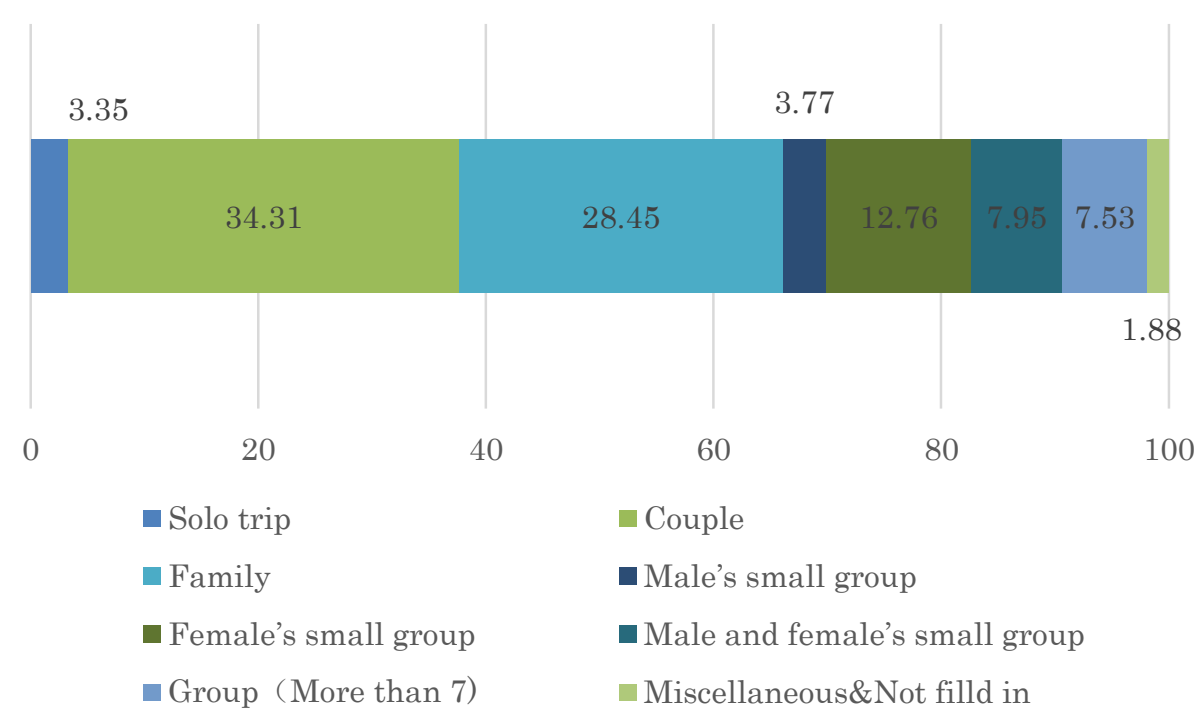

Figure 1. Fellow travelers

(6) Visiting frequency to Izu Peninsula and Kawazu Cherry Tree:

Izu Peninsula=(1)First time $18.62 \%$ (2)Second times $11.09 \%$ (3)Third times 9.83\% (4)Fourth times $5.86 \%$ (5)Fifth Nine times $15.90 \%$ (6)More than ten times 37.66\%, (Not filled in 1.05\%)

Kawazu Cherry Tree =(1)First time $48.95 \%$ (2)Second times $16.53 \%$ (3)Third times $10.46 \%$ (4)Fourth times $4.60 \%$ (5)Fifth Nine times $6.07 \%$ (6) More than ten times $7.74 \%$ (7) Has not been there 3.97\%, (Not filled in $3.97 \%$ )

2.2.2 Main Occasion to Visit to Izu Peninsula

Main occasion to visit to Izu Peninsula is exhibited in Figure 2. 


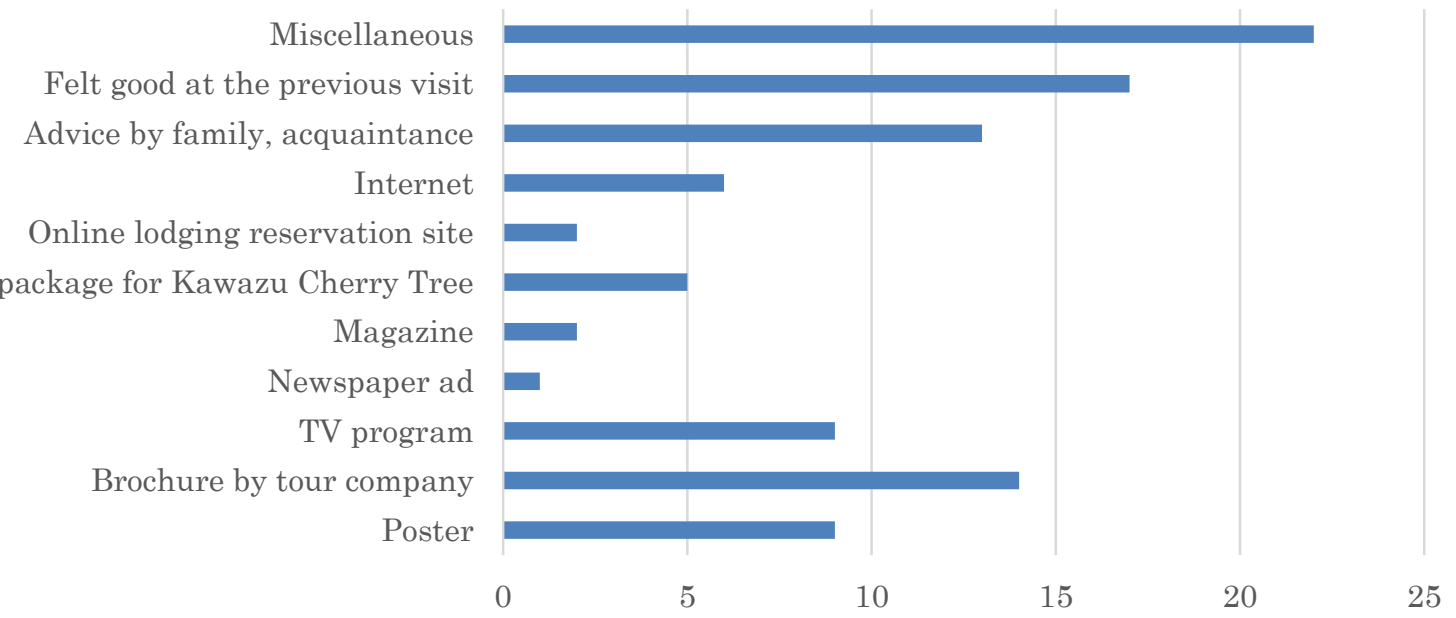

Figure 2. Main occasion to visit to Izu Peninsula

\subsubsection{An Objective to Visit Izu Peninsula}

An objective to visit Izu Peninsula is exhibited in Figure 3.

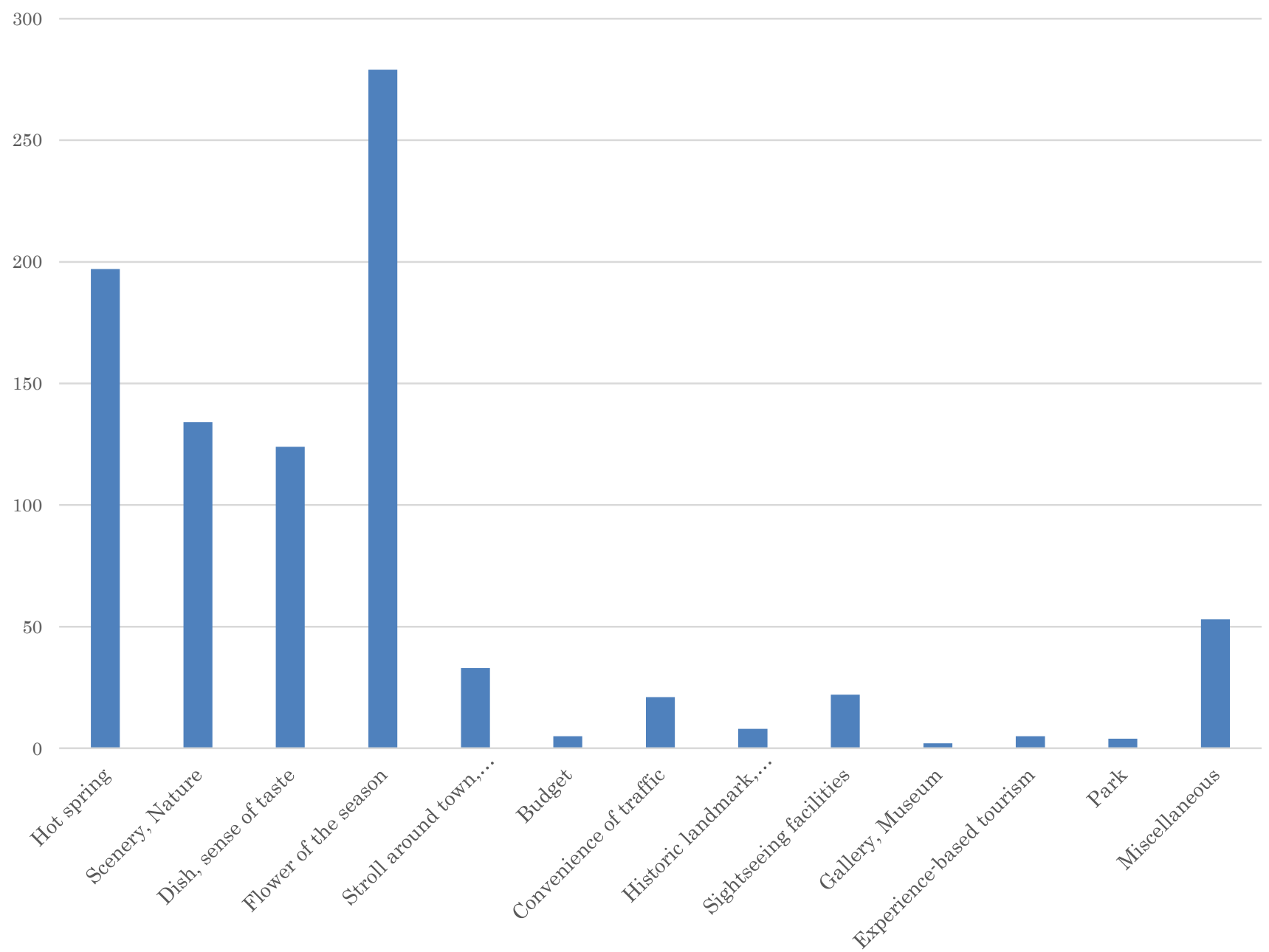

Figure 3. An objective to Izu peninsula 


\section{Bayesian Network Analysis}

In constructing Bayesian Network, it is required to check the causal relationship among groups of items.

Based on this, a model is built as is shown in Figure 4.

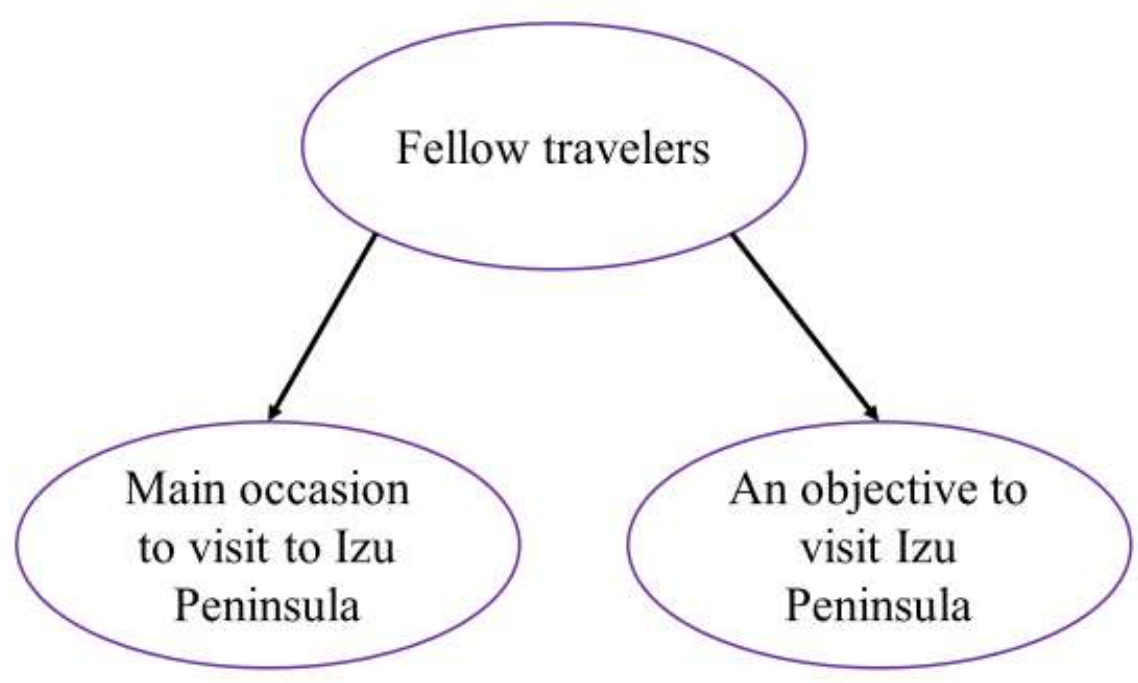

Figure 4. A Built Model

We used BAYONET software (http://www.msi.co.jp/BAYONET/). When plural nodes exist in the same group, it occurs that causal relationship is hard to set a priori. In that case, BAYONET system set the sequence automatically utilizing AIC standard.

\section{Sensitivity Analysis}

Now, posterior probability is calculated by setting evidence as, for example, 1.0. Comparing Prior probability and Posterior probability, we can seek the change and confirm the preference for tourism. We set evidence to all parameters. Therefore the analysis volume becomes too large. In this paper, we pick up half of the total cases and make analysis. Nodes we analyze here are "Fellow travelers", "Main occasion to visit Izu Peninsula" and "An objective to visit Izu Peninsula". We prepare another paper for the latter half.

As stated above, we set evidence for each parameter, and the calculated posterior probability is exhibited in Appendix 2. The value of "Posterior probability - Prior probability" (we call this "Difference of probability" hereafter) is exhibited in Appendix 3. The sensitivity analysis is executed by mainly using this table.

Here, we classify each item by the strength of the difference of probability.

- Strong (++,--): Select major parameter of which absolute value of difference of probability is more than 0.1

- Medium (+,-): Select major parameter of which absolute value of difference of probability is more than 0.07

- Weak: Else

In selecting items, negative value does not necessarily have distinct meaning, therefore we mainly pick up positive value in the case meaning is not clear.

Now we examine each for Strong and Medium case.

4.1 Sensitively Analysis for "An Objective to Visit Izu Peninsula"

(1) Setting evidence to "Hot spring"

After setting evidence to "Hot spring", the result is exhibited in Table 1. 
Table 1. Setting evidence to "Hot spring" case

\begin{tabular}{ll}
\hline Solo trip & ++ \\
\hline Family & - \\
\hline
\end{tabular}

We can observe that "Those who put "Hot spring" as an objective to visit Izu Peninsula had come by "Solo trip"”. (Strong part is indicated by bold font.)

(2) Setting evidence to "Scenery, Nature"

After setting evidence to "Scenery, Nature", the result is exhibited in Table 2.

Table 2. Setting evidence to "Scenery, Nature" case

Solo trip ++

We can observe that "Those who put "Scenery, Nature" as an objective to visit Izu Peninsula had come by "Solo trip"”.

(3) Setting evidence to "Dish, sense of taste"

After setting evidence to "Dish, sense of taste", the result is exhibited in Table 3.

Table 3. Setting evidence to "Dish, sense of taste" case

\begin{tabular}{ll}
\hline Solo trip & ++ \\
\hline Male's small group & ++ \\
Female's small group & ++ \\
Male and female's small group & + \\
Gallery, Museum & + \\
\hline
\end{tabular}

We can observe that "Those who put "Dish, sense of taste" as an objective to visit Izu Peninsula had come by "Solo trip," "Male's small group," "Female's small group" or "Male and female's small group" with an objective of visiting "Gallery, Museum"”.

(4) Setting evidence to "Flower of the season"

After setting evidence to "Flower of the season", the result is exhibited in Table 4.

Table 4. Setting evidence to "Flower of the season" case

\begin{tabular}{ll}
\hline Solo trip & ++ \\
\hline Male's small group & -- \\
Group(More than 7) & -- \\
Budget & -- \\
Convenience of traffic & - \\
Historic landmark, Literature monument, Construction & -- \\
Sightseeing facilities & - \\
Gallery, Museum & -- \\
Experience-based tourism & -- \\
Park & --
\end{tabular}

We can observe that "Those who put "Flower of the season" as an objective to visit Izu Peninsula had come by "Solo trip"”.

(5) Setting evidence to "Stroll around town, Eating tour"

After setting evidence to "Stroll around town, Eating tour", the result is exhibited in Table 5. 
Table 5. Setting evidence to "Stroll around town, Eating tour" case

\begin{tabular}{ll}
\hline Male's small group & ++ \\
\hline Budget & + \\
Convenience of traffic & + \\
Historic landmark, Literature monument, Construction & + \\
Gallery, Museum & ++ \\
Experience-based tourism & + \\
Park & +
\end{tabular}

We can observe that "Those who put "Stroll around town, Eating tour" as an objective to visit Izu Peninsula had come by "Male's small group "with an objective of visiting" (suitable)Budget", "Convenience of traffic", "Historic landmark, Literature monument, Construction"," Gallery, Museum", "Experience-based tourism" or "Park"".

(6) Setting evidence to "Budget"

After setting evidence to "Budget", the result is exhibited in Table 6.

Table 6. Setting evidence to "Budget" case

\begin{tabular}{ll}
\hline Solo trip & ++ \\
\hline Male's small group & ++ \\
Budget & + \\
Convenience of traffic & + \\
Historic landmark, Literature monument, Construction & + \\
Gallery, Museum & ++ \\
Experience-based tourism & + \\
Park & +
\end{tabular}

We can observe that "Those who put "Budget" as an objective to visit Izu Peninsula had come by "Solo trip" or "Male's small group" with an objective of visiting "(suitable)Budget", "Convenience of traffic", "Historic landmark, Literature monument, Construction"," Gallery, Museum", "Experience-based tourism" or "Park"”.

(7) Setting evidence to "Convenience of traffic"

After setting evidence to "Convenience of traffic", the result is exhibited in Table 7.

Table 7. Setting evidence to "Convenience of traffic" case

\begin{tabular}{ll}
\hline Male's small group & ++ \\
\hline Budget & + \\
Historic landmark, Literature monument, Construction & + \\
Sightseeing facilities & + \\
Gallery, Museum & ++ \\
Experience-based tourism & + \\
Park & +
\end{tabular}

We can observe that "Those who put "Convenience of traffic" as an objective to visit Izu Peninsula had come by "Male's small group" with an objective of visiting "(suitable)Budget", "Historic landmark, Literature monument, Construction", "Sightseeing facilities", Gallery, Museum", "Experience-based tourism” or" Park”".

(8) Setting evidence to "Historic landmark, Literature monument, Construction"

After setting evidence to "Historic landmark, Literature monument, Construction", the result is exhibited in Table 8. 
Table 8. Setting evidence to "Historic landmark, Literature monument, Construction" case

\begin{tabular}{lc}
\hline Solo trip & ++ \\
\hline Male's small group & ++ \\
Newspaper ad & + \\
Budget & ++ \\
Sightseeing facilities & + \\
Gallery, Museum & ++ \\
Experience-based tourism & ++ \\
Park & + \\
\hline
\end{tabular}

We can observe that "Those who put "Historic landmark, Literature monument, Construction" as an objective to visit Izu Peninsula had come by "Solo trip" or "Male's small group" under the main occasion to visit there by "Newspaper ad" with an objective of visiting" (suitable)Budget", "Sightseeing facilities", "Gallery, Museum"," Experience-based tourism" or "Park"".

(9) Setting evidence to "Sightseeing facilities"

After setting evidence to "Sightseeing facilities", the result is exhibited in Table 9.

Table 9. Setting evidence to "Sightseeing facilities" case

\begin{tabular}{lc}
\hline Solo trip & ++ \\
\hline Male's small group & ++ \\
Group(More than 7) & + \\
Budget & + \\
Historic landmark, Literature monument, & Construction \\
Experience-based tourism & + \\
Park & + \\
\hline
\end{tabular}

We can observe that "Those who put "Sightseeing facilities" as an objective to visit Izu Peninsula had come by "Solo trip" or "Male's small group" or "Group(More than 7") with an objective of visiting "(suitable)Budget", "Historic landmark, Literature monument, Construction", "Experience-based tourism” or" Park"”.

(10) Setting evidence to "Gallery, Museum"

After setting evidence to "Gallery, Museum", the result is exhibited in Table 10.

Table 10. Setting evidence to "Gallery, Museum" case

\begin{tabular}{lc}
\hline Solo trip & ++ \\
\hline Male's small group & ++ \\
Budget & + \\
Historic landmark, Literature monument, & Construction \\
Experience-based tourism & + \\
Park & + \\
\hline
\end{tabular}

We can observe that "Those who put "Gallery, Museum" as an objective to visit Izu Peninsula had come by" Solo trip "or "Male's small group" with an objective of visiting "(suitable)Budget", "Historic landmark, Literature monument, Construction"," Experience-based tourism" or "Park"”.

(11) Setting evidence to "Experience-based tourism"

After setting evidence to "Experience-based tourism", the result is exhibited in Table 11. 
Table 11. Setting evidence to "Experience-based tourism" case

\begin{tabular}{lc}
\hline Solo trip & ++ \\
\hline Male's small group & ++ \\
Budget & + \\
Historic landmark, Literature monument, & Construction \\
Gallery, Museum & + \\
Park & ++ \\
\hline
\end{tabular}

We can observe that "Those who put "Experience-based tourism" as an objective to visit Izu Peninsula had come by "Solo trip" or "Male's small group" with an objective of visiting "(suitable)Budget", "Historic landmark, Literature monument, Construction", "Gallery, Museum" or "Park"”.

(12) Setting evidence to "Park"

After setting evidence to "Park", the result is exhibited in Table 12.

Table 12. Setting evidence to "Park" case

\begin{tabular}{lc}
\hline Solo trip & ++ \\
\hline Male's small group & ++ \\
Budget & + \\
Historic landmark, Literature monument, & Construction \\
Gallery, Museum & + \\
Experience-based tourism & ++ \\
\hline
\end{tabular}

We can observe that "Those who put "Park" as an objective to visit Izu Peninsula had come by "Solo trip" or" Male's small group" with an objective of visiting "(suitable)Budget", "Historic landmark, Literature monument, Construction", "Gallery, Museum" or "Experience-based tourism"”.

\section{Remarks}

The Results for Bayesian Network Analysis are as follows.

In the Bayesian Network Analysis, model was built under the examination of the causal relationship among items. Sensitively Analysis was conducted after that. The main result of sensitively analysis is as follows.

We can observe that "Those who put "Dish, sense of taste" as an objective to visit Izu Peninsula had come by "Solo trip", "Male's small group", "Female's small group" or "Male and female's small group" with an objective of visiting "Gallery, Museum"”.

We can observe that "Those who put "Sightseeing facilities" as an objective to visit Izu Peninsula had come by "Solo trip" or "Male's small group" or "Group(More than 7)" with an objective of visiting "(suitable)Budget", "Historic landmark, Literature monument, Construction", "Experience-based tourism" or "Park"”.

\section{Conclusion}

In this paper, a questionnaire investigation is executed in order to clarify tourists' behavior, and to seek the possibility of developing regional collaboration among local government, tourism related industry and visitors. This survey of tourist behavior was carried out in February 2015, during the Kawazu Cherry Blossom Festival). The 25th Kawazu Cherry Blossom Festival was held from February 10 to March 10, 2015. It was attended by 801,330 people, which was an increase of $9 \%$ over the previous year. On the first day of the survey, 30-50\% of the flowers were in bloom, and the nighttime illuminations lit up on the evening of the 21 st. According to the figures of the Kawazu town Tourist Association, there were 30,590 visitors on the 21st and 20,913 visitors on the 22nd.

During the Kawazu Cherry Blossom Festival, around 150 stores were offering food \& drink or souvenirs on the road with the row of cherry trees linked to Kawazu Station. A number of events were held during the festival, including the "Semi Gourmet" and "Izu no Odoriko Photography Event."

At around the same time (January 20 to March 31), the 18th "Hina no Tsurushikazari Festival" (Hanging Doll Festival) was held at Higashiizu town Inatori.

In order to look for policies for effective use of questionnaire surveys in tourist destinations, the present study 
reviewed preceding studies in the field. Moreover, an attempt was made to find possibilities for inter-regional cooperation based on the data.

In the Bayesian Network Analysis, model was built under the examination of the causal relationship among items. Sensitively Analysis was conducted after that. Sensitivity analysis was achieved by back propagation method. Although it has a limitation that it is restricted in the number of research, we could obtain the fruitful results.

In the future, it will be necessary to continue such surveys at various locations on the Izu Peninsula using a standardized set of questionnaire items and methods, and the efficacy of the study will have to be confirmed.

\section{Acknowledgements}

This study was made possible through the extensive cooperation of the Izu DMO Council, Shizuoka Prefecture Government, Kawazu Town Office, JTB Chubu Office, and others. And finally, I would like to offer my deepest thanks to everybody else who has helped me in preparing this study.

\section{References}

Atami city. (2015). 2014 Survey of Tourist Behavior.

Doi, Hideji. (2009). Evaluation of policies to build tourist destinations and statistical analysis. Nippon Hyoron Sha.

http://www.kawazu-onsen.com/eng/

https://www.jnto.go.jp/eng/location/rtg/pdf/pg-410.pdf\#search='Izupeninsula'

Japan Tourism Agency. (2015). Research study on economic impacts of tourism in Japan 2013, p3.

Kano, Michiko. (2011). Characteristic analysis of Atami tourists: Reconsideration based on data add and modify. Shizuoka Economic Research, 16(2), 61-78. Shizuoka University.

Shioya, Hideo. (2009). Overview and application of tourism statistics: Analysis using statistical survey on overnight travels. Journal of Economic Structures, 17(1-2), 16-29. Pan Pacific Association of Input-Output Studies. https://doi.org/10.11107/papaios.17.1-2_16

Yoshida, Ituki. (2009). Consideration on the Characteristic of Visitors' Activity and the Research Method for Tourist Visitors in Urban Areas. 


\section{APPENDIX 1}

\section{Questionnaire about the Tourism in Izu Peninsula}

Please select the appropriate item in each column. Please write down the details in ( ).

Q1. Address:Prefecture( )

$\Rightarrow$ If the prefecture is Tokyo, Kanagawa, Shizuoka, then City(

)

Q2. Sex: (1)Male (2)Female

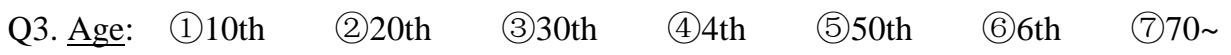

Q4. Occupation: (1)Independents (2) Office worker (3)Student (4)Housewife (5)No job (6)

Miscellaneous( )

Q5. Fellow travelers:

$\begin{array}{llll}\text { (1)Solo trip (2) Couple (3)Family } & \text { (4) Male's small group (5)Female's small group }\end{array}$

(6)Male and female's small group (7)Group(More than 7) (8)Miscellaneous( )

Q6. Visiting frequency to Izu Peninsula and Kawazu Cherry Tree:

$\begin{array}{llll}\text { Izu Peninsula=(1)First time } & \text { (2)Second times } & \text { (3)Third times } & \text { (4)Fourth times }\end{array}$

times (6) More than ten times

$\begin{array}{llll}\text { Kawazu Cherry Tree = } 1 \text { First time (2) Second times } & \text { (3) Third times } & \text { (4) Fourth times } & \text { (5) Fifth Nine }\end{array}$ times (6)More than ten times

Q7. Means of transportation to IZU Peninsula:

(1)JR, Izu-kyuko train (2)Sightseeing bus (3)Private automobile (4)Rent-a car (5)Highway bus (6)Shuttle bus service by the hotel (7) Miscellaneous( )

Q8. Means of movement in Izu Peninsula:(Plural answers allowed)

$\begin{array}{lllll}\text { (1)Walking (2) Fixed-route bus } & \text { (3) Sightseeing bus } & \text { (4) Private automobile } & \text { (5) Rent-a car (6) }\end{array}$

Taxi (7)Miscellaneous( )

$\rightarrow$ To whom who has selected (5):Starting point( ) End point( )

Q9. Main occasion to visit to Izu Peninsula(Plural answers allowed)

$\begin{array}{llll}\text { (1)Poster (2) Brochure by tour company } & \text { (3) TV program } & \text { (4) Newspaper ad } & \text { (5)Magazine }\end{array}$

(6) Tour package for Kawazu Cherry Tree (7) Online lodging reservation site (8Internet (9)Advice by family, acquaintance (10Felt good at the previous visit (11)Miscellaneous( )

Q10. What is an objective to visit Izu Peninsula?(Plural answers allowed)

(1)Hot spring (2)Scenery, Nature (3)Dish, sense of taste (4)Flower of the season (5) Stroll around town, Eating tour (6)Budget (7) Convenience of traffic (8)Historic landmark, Literature monument, Construction (9) Sightseeing facilities (10) Gallery, Museum (11)Experience-based tourism (12)Park (13)Miscellaneous( )

Q11. Staying time in Izu Peninsula:

$\begin{array}{llll}\text { (1) One - day trip } \quad \text { hour } & \text { (2) } 2 \text { days stay } & \text { (3) } 3 \text { days stay } & \text { (4)More than } 4 \text { days }\end{array}$

$\Rightarrow$ If you have selected (2) (4), please answer the following question.

(1)Staying type: (1) Inn, Hotel (2) Resort house (3) Second house (4) Relative's house (5) Miscellaneous( )
(2)Use type of staying facilities:(1)Per night with dinner and breakfast (2)Per night with dinner (3)Per night with breakfast (4)With no meals (5)Miscellaneous( )

Q12. Where are you going to go in Izu Peninsula? ※Place at which staying time is more than 30 minutes

$\star$ Customer type( ):A:One - day trip, Depart from Kawazu Cherry Tree B:One - day trip, Depart from elsewhere except for Kawazu Cherry Tree C:Stay more than one night, Depart from Kawazu Cherry Tree D:Stay more than one night, Depart from elsewhere except for Kawazu Cherry Tree 
(1) Facilities to call at

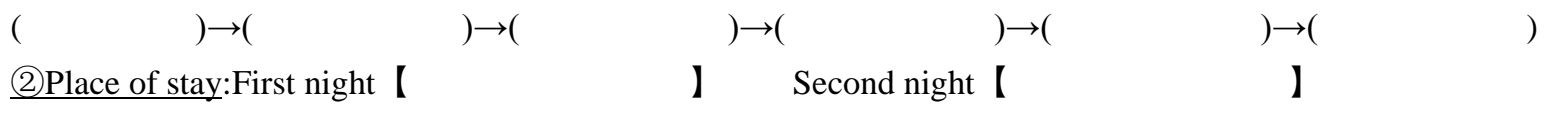

Q13. Do you want to come to Izu Peninsula again?

Q13-A: (1)Want to come again (2)Slightly want to come again (3)Slightly do not want to come again (4)Do not want to come again

$\Rightarrow$ To whom who has selected (1) and (2): What was good in Izu Peninsula?

(

To whom who has selected (3) and (4): What was not good in Izu Peninsula? (

Q13-B: What season do you want to come to Izu Peninsula? (1) Spring Month( ) Summer Month( )(3)Autumn Month( )(4)Winter Month( )

Q14. Select items in each theme concerning the attractiveness of southern part of Izu Peninsula.(Plural answers allowed)

Theme 1"sea": (1) Sea bathing (2) Activities such as diving and fishing (3)Pleasure cruiser (4) Sunset (5)Driving along the coastline (6)Open - air bath where the visitor can see the sea (7)Fresh products of the sea

Theme 2"Hot spring": (1)Feelings of the hot spring district (2)Japanese-style hotel (3)Open - air bath (4)Dinner in the hotel (5)Hospitality

Theme 3"Nature":(1)Flower of the season (2)Hiking, stroll (3)Geopark (4)Experience-oriented program (5) Mount Fuji (6) Warm climate

Theme 4"Culture":(1)Temples and shrines (2)Letter bearing the shogun's scarlet seal (Voucher seals of visit) Stroll around town (4)Folk craft goods (5)Local dishes

Miscellaneous: I II I

Q15. What do you want to be enhanced while travelling southern part of Izu Peninsula?(Plural answers allowed)

(1)Area map of southern part of Izu Peninsula (2)Total WEB site (3)Model tourism plan of southern part of Izu Peninsula (4)Tourism information for driving (5)Information for the landing-type tourism such as experience-based plan (6)Information about restaurant and shop (7)Enhancement of alternative traffic and their information (8) Miscellaneous(

Q16. How about the expenditure or budget of the following items in Izu Peninsula?
(1) Lodging expense:1) 10,000(Yen)
$\begin{array}{llll}\text { (2) } 10,001 \sim 15,000 & \text { (3) } 15,001 \sim 20,000 & \text { (4) } 20,001 \sim 30,000 & \text { (5) } 30,001 \sim\end{array}$
$\begin{array}{lllll}\text { (2) Food and drink expense:(1) 1,000 } & \text { (2) } 1,001 \sim 2,000 & \text { (3) } 2,001 \sim 3,000 & \text { (4) } 3,001 \sim 5,000 & \text { (5) } 5,001 \sim\end{array}$
$\begin{array}{lllll}\text { (3) Souvenir, Shopping:(1) 1,000 } & \text { (2)1,001 2,000 } & \text { (3)2,001 3,000 } & \text { (4) } 3,001 \sim 5,000 & \text { (5) } 5,001 \sim\end{array}$
$\begin{array}{llll}\text { (4) Miscellaneous:(1) 1,000 (2)1,001 2,000 (3)2,001 3,000 } & \text { (4)3,001 5,000 (5)5,001 }\end{array}$ 


\section{APPENDIX 2}

\section{Calculated posterior probability}

\begin{tabular}{|c|c|c|c|c|c|c|c|c|c|c|c|c|c|c|c|c|c|c|c|}
\hline \multirow[b]{2}{*}{ name } & \multirow[b]{2}{*}{ state } & \multirow[b]{2}{*}{ Prior } & \multicolumn{7}{|c|}{ Fellow travelers } & \multicolumn{10}{|c|}{ Main occasion to visit to Izu Peninsula } \\
\hline & & & Sob trip & Couple & Family & $\begin{array}{c}\text { Male's snall } \\
\text { group }\end{array}$ & $\begin{array}{c}\text { Fenale's small } \\
\text { group }\end{array}$ & \begin{tabular}{|c}
$\begin{array}{c}\text { Male and } \\
\text { femme's small } \\
\text { group }\end{array}$ \\
\end{tabular} & $\begin{array}{c}\text { Group (More } \\
\text { than 7) }\end{array}$ & Poster & $\begin{array}{c}\text { Brochure by } \\
\text { tour company }\end{array}$ & $\mathrm{TV}$ program & Newspaper ad & Magazine & $\begin{array}{l}\text { Tour package } \\
\text { for Kawazu } \\
\text { Cherry Tree }\end{array}$ & \begin{tabular}{|c} 
Online lodging \\
reservation site
\end{tabular} & Internet & $\begin{array}{c}\text { Advice by } \\
\text { family, } \\
\text { acquaintance }\end{array}$ & \begin{tabular}{|c}
$\begin{array}{c}\text { Felt good at the } \\
\text { previous viti }\end{array}$ \\
the
\end{tabular} \\
\hline \multirow{7}{*}{ Fellow travelers } & Solb trip & 0.024 & 1 & 0 & 0 & 0 & 0 & 0 & 0 & 0.06 & 0.026 & 0.027 & 0.094 & 0.062 & 0.04 & 0.071 & 0.098 & 0.034 & 0.027 \\
\hline & Couple & 0.337 & 0 & 1 & 0 & 0 & 0 & 0 & 0 & 0.375 & 0.295 & 0.331 & 0.317 & 0.278 & 0.313 & 0.402 & 0.405 & 0.191 & 0.334 \\
\hline & Faanily & 0.353 & 0 & 0 & 1 & 0 & 0 & 0 & 0 & 0.341 & 0.324 & 0.346 & 0.106 & 0.209 & 0.314 & 0.08 & 0.258 & 0.325 & 0.38 \\
\hline & $\begin{array}{c}\text { Mal's small } \\
\text { group }\end{array}$ & 0.04 & 0 & 0 & 0 & 1 & 0 & 0 & 0 & 0.032 & 0.055 & 0.042 & 0.098 & 0.064 & 0.042 & 0.075 & 0.034 & 0.053 & 0.042 \\
\hline & 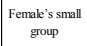 & 0.099 & 0 & 0 & 0 & 0 & 1 & 0 & 0 & 0.1 & 0.086 & 0.1 & 0.103 & 0.135 & 0.044 & 0.157 & 0.072 & 0.13 & 0.089 \\
\hline & $\begin{array}{c}\text { Male and } \\
\text { fenme's snall } \\
\text { group }\end{array}$ & 0.083 & 0 & 0 & 0 & 0 & 0 & 1 & 0 & 0.033 & 0.086 & 0.085 & 0.102 & 0.067 & 0.087 & 0.078 & 0.036 & 0.129 & 0.103 \\
\hline & $\begin{array}{c}\text { Group (More } \\
\text { than 7) }\end{array}$ & 0.056 & 0 & 0 & 0 & 0 & 0 & 0 & 1 & 0.032 & 0.084 & 0.058 & 0.1 & 0.132 & 0.127 & 0.076 & 0.07 & 0.109 & 0.014 \\
\hline \multirow{10}{*}{$\begin{array}{c}\text { Main occasion to } \\
\text { visit to Izu } \\
\text { Peninsula }\end{array}$} & Poster & 0.087 & 0.25 & 0.126 & 0.11 & 0.083 & 0.111 & 0.043 & 0.063 & 1 & 0.114 & 0.111 & 0.125 & 0.118 & 0.113 & 0.124 & 0.128 & 0.107 & 0.112 \\
\hline & $\begin{array}{l}\text { Brochure by } \\
\text { tour conpany }\end{array}$ & 0.11 & 0.125 & 0.115 & 0.121 & 0.167 & 0.111 & 0.13 & 0.188 & 0.132 & 1 & 0.129 & 0.161 & 0.151 & 0.143 & 0.15 & 0.135 & 0.141 & 0.126 \\
\hline & TV program & 0.087 & 0.094 & 0.094 & 0.094 & 0.094 & 0.096 & 0.098 & 0.101 & 0.092 & 0.09 & 1 & 0.088 & 0.099 & 0.101 & 0.088 & 0.094 & 0.09 & 0.089 \\
\hline & Newspaper ad & 0.008 & 0.125 & 0.034 & 0.011 & 0.083 & 0.037 & 0.043 & 0.063 & 0.041 & 0.045 & 0.036 & 1 & 0.054 & 0.045 & 0.059 & 0.047 & 0.043 & 0.034 \\
\hline & Magazine & 0.028 & 0.125 & 0.046 & 0.033 & 0.083 & 0.074 & 0.043 & 0.125 & 0.058 & 0.064 & 0.055 & 0.083 & 1 & 0.065 & 0.076 & 0.065 & 0.064 & 0.05 \\
\hline & \begin{tabular}{|l} 
Tour package \\
for Kavazu \\
Cherry Tree
\end{tabular} & 0.059 & 0.125 & 0.08 & 0.077 & 0.083 & 0.037 & 0.087 & 0.188 & 0.086 & 0.094 & 0.085 & 0.105 & 0.1 & 1 & 0.096 & 0.093 & 0.093 & 0.081 \\
\hline & $\begin{array}{l}\text { Oolline lodging } \\
\text { reservation site }\end{array}$ & 0.02 & 0.125 & 0.057 & 0.011 & 0.083 & 0.074 & 0.043 & 0.063 & 0.053 & 0.055 & 0.047 & 0.078 & 0.066 & 0.053 & 1 & 0.059 & 0.053 & 0.045 \\
\hline & Intemet & 0.079 & 0.375 & 0.126 & 0.077 & 0.083 & 0.074 & 0.043 & 0.125 & 0.118 & 0.108 & 0.103 & 0.136 & 0.122 & 0.114 & 0.13 & 1 & 0.102 & 0.101 \\
\hline & \begin{tabular}{|c} 
Advice by \\
family, \\
acquaninance
\end{tabular} & 0.181 & 0.25 & 0.115 & 0.187 & 0.25 & 0.259 & 0.304 & 0.375 & 0.191 & 0.217 & 0.199 & 0.24 & 0.234 & 0.217 & 0.221 & 0.197 & 1 & 0.192 \\
\hline & \begin{tabular}{|c|} 
Felt good at the \\
previous visit
\end{tabular} & 0.244 & 0.25 & 0.253 & 0.275 & 0.25 & 0.222 & 0.304 & 0.063 & 0.252 & 0.245 & 0.251 & 0.237 & 0.231 & 0.238 & 0.239 & 0.244 & 0.242 & 1 \\
\hline \multirow{12}{*}{$\begin{array}{c}\text { An objective to } \\
\text { visit Izu } \\
\text { Peninsula }\end{array}$} & Hot spring & 0.445 & 0.625 & 0.552 & 0.352 & 0.5 & 0.407 & 0.391 & 0.438 & 0.455 & 0.437 & 0.444 & 0.465 & 0.45 & 0.445 & 0.475 & 0.473 & 0.426 & 0.441 \\
\hline & Scenery, Nature & 0.24 & 0.5 & 0.244 & 0.264 & 0.25 & 0.296 & 0.261 & 0.188 & 0.271 & 0.259 & 0.262 & 0.273 & 0.265 & 0.257 & 0.27 & 0.275 & 0.262 & 0.264 \\
\hline & $\begin{array}{c}\text { Dish, sense of } \\
\text { taste }\end{array}$ & 0.295 & 0.125 & 0.287 & 0.264 & 0.5 & 0.407 & 0.391 & 0.25 & 0.296 & 0.313 & 0.305 & 0.327 & 0.316 & 0.299 & 0.327 & 0.288 & 0.317 & 0.306 \\
\hline & $\begin{array}{c}\text { Flower of the } \\
\text { season }\end{array}$ & 0.669 & 0.375 & 0.701 & 0.703 & 0.417 & 0.667 & 0.696 & 0.563 & 0.653 & 0.643 & 0.664 & 0.589 & 0.616 & 0.642 & 0.613 & 0.635 & 0.642 & 0.67 \\
\hline & \begin{tabular}{|c|} 
Stroll around \\
town, Eating \\
tour
\end{tabular} & 0.059 & 0.125 & 0.103 & 0.033 & 0.333 & 0.111 & 0.043 & 0.063 & 0.089 & 0.092 & 0.084 & 0.123 & 0.104 & 0.087 & 0.119 & 0.095 & 0.087 & 0.083 \\
\hline & Budget & 0.004 & 0.125 & 0.011 & 0.011 & 0.167 & 0.037 & 0.043 & 0.063 & 0.035 & 0.043 & 0.032 & 0.067 & 0.053 & 0.041 & 0.056 & 0.041 & 0.043 & 0.03 \\
\hline & $\begin{array}{c}\text { Convenience of } \\
\text { traffic }\end{array}$ & 0.059 & 0.125 & 0.08 & 0.044 & 0.333 & 0.074 & 0.043 & 0.125 & 0.083 & 0.091 & 0.08 & 0.119 & 0.103 & 0.089 & 0.109 & 0.09 & 0.088 & 0.077 \\
\hline & 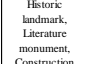 & 0.02 & 0.25 & 0.034 & 0.011 & 0.25 & 0.037 & 0.043 & 0.063 & 0.053 & 0.057 & 0.046 & 0.095 & 0.073 & 0.056 & 0.08 & 0.065 & 0.056 & 0.044 \\
\hline & $\begin{array}{c}\text { Sightseeing } \\
\text { facilities }\end{array}$ & 0.051 & 0.25 & 0.023 & 0.066 & 0.333 & 0.074 & 0.043 & 0.125 & 0.076 & 0.085 & 0.072 & 0.115 & 0.1 & 0.083 & 0.097 & 0.085 & 0.088 & 0.069 \\
\hline & $\begin{array}{l}\text { Gallery, } \\
\text { Museum }\end{array}$ & 0.004 & 0.125 & 0.011 & 0.011 & 0.167 & 0.037 & 0.043 & 0.063 & 0.035 & 0.043 & 0.032 & 0.067 & 0.053 & 0.041 & 0.056 & 0.041 & 0.043 & 0.03 \\
\hline & \begin{tabular}{|l} 
Experience- \\
based tourism
\end{tabular} & 0.008 & 0.125 & 0.011 & 0.011 & 0.167 & 0.037 & 0.043 & 0.063 & 0.035 & 0.043 & 0.032 & 0.067 & 0.053 & 0.041 & 0.056 & 0.041 & 0.043 & 0.03 \\
\hline & Park & 0.008 & 0.125 & 0.023 & 0.011 & 0.167 & 0.037 & 0.043 & 0.063 & 0.039 & 0.046 & 0.036 & 0.071 & 0.056 & 0.044 & 0.061 & 0.046 & 0.046 & 0.034 \\
\hline
\end{tabular}




\begin{tabular}{|c|c|c|c|c|c|c|c|c|c|c|c|}
\hline \multicolumn{12}{|c|}{ An objective to visit Izu Peninsula } \\
\hline $\begin{array}{l}\text { Hot } \\
\text { sprin } \\
\text { g }\end{array}$ & $\begin{array}{l}\text { Scenery } \\
\text {, Nature }\end{array}$ & $\begin{array}{c}\text { Dish, } \\
\text { sense } \\
\text { of } \\
\text { taste }\end{array}$ & $\begin{array}{c}\text { Flowe } \\
\text { r of } \\
\text { the } \\
\text { seaso } \\
n\end{array}$ & $\begin{array}{l}\text { Stroll } \\
\text { aroun } \\
\mathrm{d} \\
\text { town, } \\
\text { Eatin } \\
\mathrm{g} \text { tour }\end{array}$ & $\begin{array}{c}\text { Budg } \\
\text { et }\end{array}$ & $\begin{array}{l}\text { Convenienc } \\
\text { e of traffic }\end{array}$ & $\begin{array}{c}\text { Historic } \\
\text { landmark, } \\
\text { Literature } \\
\text { monument, } \\
\text { Constructio } \\
\text { n }\end{array}$ & $\begin{array}{l}\text { Sightseein } \\
\mathrm{g} \text { facilities }\end{array}$ & $\begin{array}{c}\text { Gallery, } \\
\text { Museu } \\
\text { m }\end{array}$ & $\begin{array}{c}\text { Experien } \\
\text { ce-based } \\
\text { tourism }\end{array}$ & Park \\
\hline 0.038 & 0.051 & 0.011 & 0.015 & 0.04 & 0.106 & 0.042 & 0.145 & 0.093 & 0.164 & 0.106 & 0.094 \\
\hline 0.411 & 0.309 & 0.312 & 0.349 & 0.406 & 0.119 & 0.331 & 0.246 & 0.105 & 0.017 & 0.119 & 0.213 \\
\hline 0.274 & 0.349 & 0.299 & 0.367 & 0.135 & 0.119 & 0.189 & 0.082 & 0.315 & 0.049 & 0.119 & 0.107 \\
\hline 0.048 & 0.04 & 0.069 & 0.027 & 0.167 & 0.221 & 0.175 & 0.228 & 0.195 & 0.458 & 0.221 & 0.198 \\
\hline 0.092 & 0.113 & 0.134 & 0.1 & 0.132 & 0.116 & 0.092 & 0.08 & 0.102 & 0.053 & 0.116 & 0.104 \\
\hline 0.075 & 0.084 & 0.109 & 0.089 & 0.044 & 0.115 & 0.046 & 0.079 & 0.051 & 0.031 & 0.115 & 0.103 \\
\hline 0.057 & 0.041 & 0.047 & 0.049 & 0.043 & 0.113 & 0.09 & 0.078 & 0.1 & 0.088 & 0.113 & 0.101 \\
\hline 0.114 & 0.115 & 0.108 & 0.11 & 0.118 & 0.121 & 0.114 & 0.128 & 0.117 & 0.134 & 0.121 & 0.121 \\
\hline 0.127 & 0.128 & 0.132 & 0.125 & 0.141 & 0.173 & 0.146 & 0.159 & 0.151 & 0.201 & 0.173 & 0.166 \\
\hline 0.096 & 0.092 & 0.088 & 0.088 & 0.09 & 0.098 & 0.095 & 0.096 & 0.09 & 0.093 & 0.091 & 0.088 \\
\hline 0.038 & 0.038 & 0.039 & 0.032 & 0.052 & 0.076 & 0.053 & 0.073 & 0.057 & 0.104 & 0.076 & 0.072 \\
\hline 0.055 & 0.056 & 0.057 & 0.051 & 0.068 & 0.091 & 0.07 & 0.086 & 0.075 & 0.112 & 0.091 & 0.087 \\
\hline 0.085 & 0.084 & 0.083 & 0.082 & 0.087 & 0.109 & 0.094 & 0.103 & 0.097 & 0.12 & 0.109 & 0.106 \\
\hline 0.051 & 0.049 & 0.051 & 0.044 & 0.067 & 0.083 & 0.064 & 0.082 & 0.063 & 0.106 & 0.083 & 0.08 \\
\hline 0.11 & 0.109 & 0.098 & 0.099 & 0.116 & 0.133 & 0.116 & 0.145 & 0.121 & 0.157 & 0.133 & 0.132 \\
\hline 0.191 & 0.2 & 0.207 & 0.193 & 0.204 & 0.27 & 0.217 & 0.242 & 0.242 & 0.293 & 0.27 & 0.254 \\
\hline 0.249 & 0.253 & 0.252 & 0.253 & 0.245 & 0.235 & 0.239 & 0.24 & 0.239 & 0.235 & 0.235 & 0.237 \\
\hline 1 & 0.446 & 0.441 & 0.442 & 0.478 & 0.449 & 0.466 & 0.482 & 0.439 & 0.465 & 0.449 & 0.46 \\
\hline 0.262 & 1 & 0.259 & 0.259 & 0.263 & 0.277 & 0.26 & 0.286 & 0.276 & 0.289 & 0.277 & 0.273 \\
\hline 0.303 & 0.303 & 1 & 0.302 & 0.339 & 0.355 & 0.333 & 0.338 & 0.329 & 0.393 & 0.355 & 0.348 \\
\hline 0.661 & 0.659 & 0.658 & 1 & 0.615 & 0.543 & 0.606 & 0.547 & 0.581 & 0.44 & 0.543 & 0.56 \\
\hline 0.091 & 0.085 & 0.094 & 0.078 & 1 & 0.151 & 0.131 & 0.155 & 0.127 & 0.224 & 0.151 & 0.146 \\
\hline 0.032 & 0.034 & 0.037 & 0.026 & 0.057 & 1 & 0.06 & 0.087 & 0.071 & 0.141 & 0.092 & 0.083 \\
\hline 0.084 & 0.08 & 0.088 & 0.073 & 0.125 & 0.152 & 1 & 0.152 & 0.131 & 0.228 & 0.152 & 0.144 \\
\hline 0.05 & 0.051 & 0.052 & 0.038 & 0.085 & 0.126 & 0.088 & 1 & 0.101 & 0.2 & 0.126 & 0.116 \\
\hline 0.072 & 0.076 & 0.078 & 0.063 & 0.109 & 0.161 & 0.118 & 0.158 & 1 & 0.063 & 0.161 & 0.146 \\
\hline 0.032 & 0.034 & 0.037 & 0.026 & 0.057 & 0.092 & 0.06 & 0.087 & 0.071 & 1 & 0.092 & 0.083 \\
\hline 0.032 & 0.034 & 0.037 & 0.026 & 0.057 & 0.092 & 0.06 & 0.087 & 0.071 & 0.141 & 1 & 0.083 \\
\hline 0.037 & 0.037 & 0.041 & 0.03 & 0.062 & 0.093 & 0.064 & 0.089 & 0.072 & 0.142 & 0.093 & 1 \\
\hline
\end{tabular}




\section{APPENDIX 3}

Difference of probability

\begin{tabular}{|c|c|c|c|c|c|c|c|c|c|c|c|c|c|c|c|c|c|c|c|}
\hline \multirow[b]{2}{*}{ name } & \multirow[b]{2}{*}{ state } & \multirow[b]{2}{*}{ Prior } & \multicolumn{7}{|c|}{ Fellow travelers } & \multicolumn{10}{|c|}{ Main occasion to visit to Izu Peninsula } \\
\hline & & & Solo trip & Couple & Fanily & $\begin{array}{c}\text { Mal's small } \\
\text { group }\end{array}$ & $\begin{array}{c}\text { Fenmale's small } \\
\text { group }\end{array}$ & $\begin{array}{l}\text { Male and } \\
\text { fenale's small } \\
\text { group }\end{array}$ & $\begin{array}{c}\text { Group }(\text { More } \\
\text { than } 7)\end{array}$ & Poster & $\begin{array}{l}\text { Brochure by } \\
\text { tour company }\end{array}$ & TV program & Newspaper ad & Magazine & $\begin{array}{l}\text { Tour package } \\
\text { for Kawazu } \\
\text { Cherry Tree }\end{array}$ & \begin{tabular}{|l} 
Online lodging \\
reservation site
\end{tabular} & Internet & $\begin{array}{c}\text { Advice by } \\
\text { family, } \\
\text { acquaintance }\end{array}$ & $\begin{array}{l}\text { Fel good at the } \\
\text { previous vist }\end{array}$ \\
\hline \multirow{7}{*}{ Fellow travelers } & Solo trip & 0.024 & 1 & 0 & 0 & 0 & 0 & 0 & 0 & 0.036 & 0.002 & 0.003 & 0.07 & 0.038 & 0.016 & 0.047 & 0.074 & 0.01 & 0.003 \\
\hline & Couple & 0.337 & 0 & 1 & 0 & 0 & 0 & 0 & 0 & 0.038 & -0.042 & -0.006 & -0.02 & -0.059 & -0.024 & 0.065 & 0.068 & -0.146 & -0.003 \\
\hline & Family & 0.353 & 0 & 0 & 1 & 0 & 0 & 0 & 0 & -0.012 & -0.029 & -0.007 & -0.247 & -0.144 & -0.039 & -0.273 & -0.095 & -0.028 & 0.027 \\
\hline & $\begin{array}{c}\text { Mala's small } \\
\text { group }\end{array}$ & 0.04 & 0 & 0 & 0 & 1 & 0 & 0 & 0 & -0.008 & 0.015 & 0.002 & 0.058 & 0.024 & 0.002 & 0.035 & -0.006 & 0.013 & 0.002 \\
\hline & $\begin{array}{c}\text { Femal's small } \\
\text { group }\end{array}$ & 0.099 & 0 & 0 & 0 & 0 & 1 & 0 & 0 & 0.001 & -0.013 & 0.001 & 0.004 & 0.036 & -0.055 & 0.058 & -0.027 & 0.031 & -0.01 \\
\hline & $\begin{array}{c}\text { Male and } \\
\text { female's small } \\
\text { group }\end{array}$ & 0.083 & 0 & 0 & 0 & 0 & 0 & 1 & 0 & -0.05 & 0.003 & 0.002 & 0.019 & -0.016 & 0.004 & -0.005 & -0.047 & 0.046 & 0.02 \\
\hline & $\begin{array}{c}\text { Group (More } \\
\text { than 7) }\end{array}$ & 0.056 & 0 & 0 & 0 & 0 & 0 & 0 & 1 & -0.024 & 0.028 & 0.002 & 0.044 & 0.076 & 0.071 & 0.02 & 0.014 & 0.053 & -0.042 \\
\hline \multirow{10}{*}{\begin{tabular}{|c} 
Main occasion to \\
visit to Izu \\
Peninsula
\end{tabular}} & Poster & 0.087 & 0.163 & 0.039 & 0.023 & -0.004 & 0.024 & -0.044 & -0.024 & 1 & 0.027 & 0.024 & 0.038 & 0.031 & 0.026 & 0.037 & 0.041 & 0.02 & 0.025 \\
\hline & $\begin{array}{l}\text { Brochure by } \\
\text { tour conpany }\end{array}$ & 0.11 & 0.015 & 0.005 & 0.011 & 0.057 & 0.001 & 0.02 & 0.078 & 0.022 & 1 & 0.019 & 0.051 & 0.041 & 0.033 & 0.04 & 0.025 & 0.031 & 0.016 \\
\hline & TV program & 0.087 & 0.007 & 0.007 & 0.007 & 0.007 & 0.009 & 0.011 & 0.014 & 0.005 & 0.003 & 1 & 0.01 & 0.012 & 0.014 & 0.01 & 0.007 & 0.003 & 0.002 \\
\hline & Newspaper ad & 0.008 & 0.117 & 0.026 & 0.003 & 0.075 & 0.029 & 0.035 & 0.055 & 0.033 & 0.037 & 0.028 & 1 & 0.046 & 0.037 & 0.051 & 0.039 & 0.035 & 0.026 \\
\hline & Magazine & 0.028 & 0.097 & 0.018 & 0.005 & 0.055 & 0.046 & 0.015 & 0.097 & 0.03 & 0.036 & 0.027 & 0.055 & 1 & 0.037 & 0.048 & 0.037 & 0.036 & 0.022 \\
\hline & $\begin{array}{c}\text { Tour package } \\
\text { for Kawazu } \\
\text { Chery Tree }\end{array}$ & 0.059 & 0.066 & 0.021 & 0.018 & 0.024 & -0.022 & 0.028 & 0.129 & 0.027 & 0.035 & 0.026 & 0.046 & 0.041 & 1 & 0.037 & 0.034 & 0.034 & 0.022 \\
\hline & $\begin{array}{l}\text { Oolline lodging } \\
\text { reservation sie }\end{array}$ & 0.02 & 0.105 & 0.037 & -0.009 & 0.063 & 0.054 & 0.023 & 0.043 & 0.033 & 0.035 & 0.027 & 0.058 & 0.046 & 0.033 & 1 & -0.079 & 0.033 & 0.025 \\
\hline & Internet & 0.079 & 0.296 & 0.047 & -0.002 & 0.004 & -0.005 & -0.036 & 0.046 & 0.039 & 0.029 & 0.024 & 0.057 & 0.043 & 0.035 & 0.051 & 1 & 0.023 & 0.022 \\
\hline & $\begin{array}{c}\text { Advice by } \\
\text { family, } \\
\text { acquantance }\end{array}$ & 0.181 & 0.069 & -0.066 & 0.006 & 0.069 & 0.078 & 0.123 & 0.194 & 0.01 & 0.036 & 0.018 & 0.059 & 0.053 & 0.036 & 0.04 & 0.016 & 1 & 0.011 \\
\hline & $\begin{array}{l}\text { Felt good at the } \\
\text { previous visit }\end{array}$ & 0.244 & 0.006 & 0.009 & 0.031 & 0.006 & -0.022 & 0.06 & -0.181 & 0.008 & 0.001 & 0.007 & -0.007 & -0.013 & -0.006 & -0.005 & 0 & -0.002 & 1 \\
\hline \multirow{12}{*}{$\begin{array}{c}\text { An objective to } \\
\text { visit Izu } \\
\text { Peninsula }\end{array}$} & Hot spring & 0.445 & 0.18 & 0.107 & -0.093 & 0.055 & -0.038 & -0.054 & -0.007 & 0.01 & -0.008 & -0.001 & 0.02 & 0.005 & 0 & 0.03 & 0.028 & -0.019 & -0.004 \\
\hline & Scenery, Nature & 0.24 & 0.26 & 0.004 & 0.024 & 0.01 & 0.056 & 0.021 & -0.052 & 0.031 & 0.019 & 0.022 & 0.033 & 0.025 & 0.017 & 0.03 & 0.035 & 0.022 & 0.024 \\
\hline & $\begin{array}{c}\text { Dish, sense of } \\
\text { taste }\end{array}$ & 0.295 & -0.17 & -0.008 & -0.031 & 0.205 & 0.112 & 0.096 & -0.045 & 0.001 & 0.018 & 0.01 & 0.032 & 0.021 & 0.004 & 0.032 & -0.007 & 0.022 & 0.011 \\
\hline & $\begin{array}{c}\text { Fbower of the } \\
\text { season }\end{array}$ & 0.669 & -0.294 & 0.032 & 0.034 & -0.252 & -0.002 & 0.027 & -0.106 & -0.016 & -0.026 & -0.005 & -0.08 & -0.053 & -0.027 & -0.056 & -0.034 & -0.027 & 0.001 \\
\hline & $\begin{array}{c}\text { Stroll around } \\
\text { town, Eating } \\
\text { tour }\end{array}$ & 0.059 & 0.066 & 0.044 & -0.026 & 0.274 & 0.052 & -0.016 & 0.004 & 0.03 & 0.033 & 0.025 & 0.064 & 0.045 & 0.028 & 0.06 & 0.036 & 0.028 & 0.024 \\
\hline & Budget & 0.004 & 0.121 & 0.007 & 0.007 & 0.163 & 0.033 & 0.039 & 0.059 & 0.031 & 0.039 & 0.028 & 0.063 & 0.049 & 0.037 & 0.052 & 0.037 & 0.039 & 0.026 \\
\hline & $\begin{array}{c}\text { Convenience of } \\
\text { traficic }\end{array}$ & 0.059 & 0.066 & 0.021 & -0.015 & 0.274 & 0.015 & -0.016 & 0.066 & 0.024 & 0.032 & 0.021 & 0.06 & 0.044 & 0.03 & 0.05 & 0.031 & 0.029 & 0.018 \\
\hline & $\begin{array}{l}\text { Hestorick } \\
\text { handmank, } \\
\text { Literature } \\
\text { monument. }\end{array}$ & 0.02 & 0.23 & 0.014 & -0.009 & 0.23 & 0.017 & 0.023 & 0.043 & 0.033 & 0.037 & 0.026 & 0.075 & 0.053 & 0.036 & 0.06 & 0.045 & 0.036 & 0.024 \\
\hline & $\begin{array}{c}\text { Sightseeing } \\
\text { ficilities }\end{array}$ & 0.051 & 0.199 & -0.028 & 0.015 & 0.282 & 0.023 & -0.008 & 0.074 & 0.025 & 0.034 & 0.021 & 0.064 & 0.049 & 0.032 & 0.046 & 0.034 & 0.037 & 0.018 \\
\hline & $\begin{array}{l}\text { Gallery, } \\
\text { Museum }\end{array}$ & 0.004 & 0.121 & 0.007 & 0.007 & 0.163 & 0.033 & 0.039 & 0.059 & 0.031 & 0.039 & 0.028 & 0.063 & 0.049 & 0.037 & 0.052 & 0.037 & 0.039 & 0.026 \\
\hline & $\begin{array}{c}\text { Experience- } \\
\text { based tourism }\end{array}$ & 0.008 & 0.117 & 0.003 & 0.003 & 0.159 & 0.029 & 0.035 & 0.055 & 0.027 & 0.035 & 0.024 & 0.059 & 0.045 & 0.033 & 0.048 & 0.033 & 0.035 & 0.022 \\
\hline & Park & 0.008 & 0.117 & 0.015 & 0.003 & 0.159 & 0.029 & 0.035 & 0.055 & 0.031 & 0.038 & 0.028 & 0.063 & 0.048 & 0.036 & 0.053 & 0.038 & 0.038 & 0.026 \\
\hline
\end{tabular}




\begin{tabular}{|c|c|c|c|c|c|c|c|c|c|c|c|}
\hline \multicolumn{12}{|c|}{ An objective to visit Izu Peninsula } \\
\hline $\begin{array}{c}\text { Hot } \\
\text { spring }\end{array}$ & $\begin{array}{c}\text { Scenery, } \\
\text { Nature }\end{array}$ & $\begin{array}{l}\text { Dish, } \\
\text { sense of } \\
\text { taste }\end{array}$ & $\begin{array}{c}\text { Flower } \\
\text { of the } \\
\text { season }\end{array}$ & $\begin{array}{l}\text { Stroll } \\
\text { around } \\
\text { town, } \\
\text { Eating } \\
\text { tour }\end{array}$ & $\begin{array}{c}\text { Budge } \\
\mathrm{t}\end{array}$ & $\begin{array}{c}\text { Convenience } \\
\text { of traffic }\end{array}$ & $\begin{array}{c}\text { Historic } \\
\text { landmark, } \\
\text { Literature } \\
\text { monument, } \\
\text { Construction }\end{array}$ & $\begin{array}{l}\text { Sightseeing } \\
\text { facilities }\end{array}$ & $\begin{array}{l}\text { Gallery, } \\
\text { Museum }\end{array}$ & $\begin{array}{c}\text { Experience- } \\
\text { based } \\
\text { tourism }\end{array}$ & Park \\
\hline 0.014 & 0.027 & -0.013 & -0.009 & 0.016 & 0.082 & 0.018 & 0.121 & 0.069 & 0.14 & 0.082 & 0.07 \\
\hline 0.074 & -0.028 & -0.025 & 0.012 & 0.069 & -0.218 & -0.006 & -0.091 & -0.232 & -0.32 & -0.218 & -0.124 \\
\hline-0.079 & -0.004 & -0.054 & 0.014 & -0.218 & -0.234 & -0.164 & -0.271 & -0.038 & -0.304 & -0.234 & -0.246 \\
\hline 0.008 & 0 & 0.029 & -0.013 & 0.127 & 0.181 & 0.135 & 0.188 & 0.155 & 0.418 & 0.181 & 0.158 \\
\hline-0.007 & 0.014 & 0.035 & 0.001 & 0.033 & 0.017 & -0.007 & -0.019 & 0.003 & -0.046 & 0.017 & 0.005 \\
\hline-0.008 & 0.001 & 0.026 & 0.006 & -0.039 & 0.032 & -0.037 & -0.004 & -0.032 & -0.052 & 0.032 & 0.02 \\
\hline 0.001 & -0.015 & -0.009 & -0.007 & -0.013 & 0.057 & 0.034 & 0.022 & 0.044 & 0.032 & 0.057 & 0.045 \\
\hline 0.027 & 0.028 & 0.021 & 0.023 & 0.031 & 0.034 & 0.027 & 0.041 & 0.03 & 0.047 & 0.034 & 0.034 \\
\hline 0.017 & 0.018 & 0.022 & 0.015 & 0.031 & 0.063 & 0.036 & 0.049 & 0.041 & 0.091 & 0.063 & 0.056 \\
\hline 0.009 & 0.005 & 0.001 & 0.001 & 0.003 & 0.011 & 0.008 & 0.009 & 0.003 & 0.006 & 0.014 & 0.001 \\
\hline 0.03 & 0.03 & 0.031 & 0.024 & 0.044 & 0.068 & 0.045 & 0.065 & 0.049 & 0.096 & 0.068 & 0.064 \\
\hline 0.027 & 0.028 & 0.029 & 0.023 & 0.04 & 0.063 & 0.042 & 0.058 & 0.047 & 0.084 & 0.063 & 0.059 \\
\hline 0.026 & 0.025 & 0.024 & 0.023 & 0.028 & 0.05 & 0.035 & 0.044 & 0.038 & 0.061 & 0.05 & 0.047 \\
\hline 0.031 & 0.029 & 0.031 & 0.024 & 0.047 & 0.063 & 0.044 & 0.062 & 0.043 & 0.086 & 0.063 & 0.06 \\
\hline 0.031 & 0.03 & 0.019 & 0.02 & 0.037 & 0.054 & 0.037 & 0.066 & 0.042 & 0.078 & 0.054 & 0.053 \\
\hline 0.01 & 0.019 & 0.026 & 0.012 & 0.023 & 0.089 & 0.036 & 0.061 & 0.061 & 0.112 & 0.089 & 0.073 \\
\hline 0.005 & 0.009 & 0.008 & 0.009 & 0.001 & -0.009 & -0.005 & -0.004 & -0.005 & -0.009 & -0.009 & -0.007 \\
\hline 1 & 0.001 & -0.004 & -0.003 & 0.033 & 0.004 & 0.021 & 0.037 & -0.006 & 0.02 & 0.004 & 0.015 \\
\hline 0.022 & 1 & 0.019 & 0.019 & 0.023 & 0.037 & 0.02 & 0.046 & 0.036 & 0.049 & 0.037 & 0.033 \\
\hline 0.008 & 0.008 & 1 & 0.007 & 0.044 & 0.06 & 0.038 & 0.043 & 0.034 & 0.098 & 0.06 & 0.053 \\
\hline-0.008 & -0.01 & -0.011 & 1 & -0.054 & -0.126 & -0.063 & -0.122 & -0.088 & -0.229 & -0.126 & -0.109 \\
\hline 0.032 & 0.026 & 0.035 & 0.019 & 1 & 0.092 & 0.072 & 0.096 & 0.068 & 0.165 & 0.092 & 0.087 \\
\hline 0.028 & 0.03 & 0.033 & 0.022 & 0.053 & 1 & 0.056 & 0.083 & 0.067 & 0.137 & 0.088 & 0.079 \\
\hline 0.025 & 0.021 & 0.029 & 0.014 & 0.066 & 0.093 & 1 & 0.093 & 0.072 & 0.169 & 0.093 & 0.085 \\
\hline 0.03 & 0.031 & 0.032 & 0.018 & 0.065 & 0.106 & 0.068 & 1 & 0.081 & 0.18 & 0.106 & 0.096 \\
\hline 0.021 & 0.025 & 0.027 & 0.012 & 0.058 & 0.11 & 0.067 & 0.107 & 1 & 0.012 & 0.11 & 0.095 \\
\hline 0.028 & 0.03 & 0.033 & 0.022 & 0.053 & 0.088 & 0.056 & 0.083 & 0.067 & 1 & 0.088 & 0.079 \\
\hline 0.024 & 0.026 & 0.029 & 0.018 & 0.049 & 0.084 & 0.052 & 0.079 & 0.063 & 0.133 & 1 & 0.075 \\
\hline 0.029 & 0.029 & 0.033 & 0.022 & 0.054 & 0.085 & 0.056 & 0.081 & 0.064 & 0.134 & 0.085 & 1 \\
\hline
\end{tabular}

